\title{
Geri Vermeye İliş̧in Düzenlemeler Çerçevesinde Hükûmete Karşı Suçun Durumu $^{*}$
}

\author{
The Situation of Crime Against the Government under Extradition \\ Regulations
}

\section{Fatma Sümer ${ }^{* *}$ (iD)}

\section{öz}

Siyasi suçlar, doktrinde kabul gören çeşitli teoriler çerçevesinde, failin saiki ve suçla korunan hukuki değer dikkate alınarak tespit edilir. Bu teoriler bağlamında yapılan bir değerlendirmeyle hükûmete karşı suçun bir siyasi suç olduğu görülmektedir. Siyasi suçlarda iade bakımından uygulama alanı bulan Suçluların İadesine Dair Avrupa Sözleşmesi’nin (SİDAS) 3/1. maddesinde siyasi saikle işlenen suçlar ve bağlı siyasi suçlarda geri vermenin uygulanmayacağı düzenlenmektedir. Bununla beraber bu kuralın teamüllerle gelişen ve SİDAS’ta da yer alan bir istisnası olan Belçika kuralı, devlet başkanına karşı işlenen suçlarda geri verme kurumunun uygulanmasını gerektirmektedir.

Zamanla adi suçların siyasi saikle işlenmeleri ya da siyasi nitelikteki hukuki değerleri korumaları halinde iade kurumunun uygulanmamasının toplumda adalet duygusunu zedelediği ve cezasızlığa yol açtığı anlayışı kabul görmüş, özellikle terör suçlarında bu sebeplerle iadeden kaçınılmasının önüne geçilmesini hedefleyen düzenlemeler ihdas edilmiştir. Hükûmete karşı suçun cebirle işlenebilen bağlı hareketli bir suç olması dolayısıyla Terörizmin Önlenmesine Dair Avrupa Sözleşmesỉnde (TÖDAS) yer alan bu çerçevedeki düzenlemeler suç tipi bakımından uygulama alanı bulabilecektir.

Anahtar Kelimeler: Siyasi Suç, Terör Suçu, Hükûmete Karşı Suç, Hükûmete Karşı Cebir, Devlet Başkanına Karşı Cebir, Belçika Kuralı, SİDAS, TÖDAS, Geri Verme

\section{ABSTRACT}

Political crimes are determined within the framework of various theories accepted in the doctrine, taking into account the motive of the perpetrator and the legal value protected by the crime. When considered within the framework of these theories, it is seen that the crime against the government is a political crime. European Convention on Extradition (ECE), which finds application in terms of extradition in political crimes, regulates that the return will not be applied for crimes committed with political motives and related political crimes (art. 3/1). However, the Belgian rule, which is an exception to this rule, which is developed with customary and is also included in the ECE, requires the implementation of the extradition institution in crimes against the head of state.

Regulations regarding political crimes also caused ordinary crimes not to be subject to extradition on the grounds that they were committed with a political motive. In time, the understanding that this situation harmed the sense of justice in the society and led to impunity began to be accepted. For these reasons, regulations were introduced to ensure extradition, especially in terrorist crimes. Since the crime against the government is a dependent and mobile crime that can be committed by force, the regulations in this framework in European Convention on the Suppression of Terrorizm (ECST) may find application area in terms of crime type.

Keywords: Political Crime, Terrorist Crime, Crime Against the Government, Violence Against the President, Belgian Rule, ECE, ECST, Extradition

* Bu makale, Marmara Üniversitesi Sosyal Bilimler Enstitüsü’nde Prof. Dr. Ahmet Gökcen danışmanlığında tamamladı̆̆ı "Hükûmete Karşı Suç (TCK m. 312)" başlıklı doktora tezinin "Hükûmete Karşı Suçun Siyasi Suç Olması ve Geri Verme Kurumu Bakımından Durumu” başlığının detaylandırılması ve kaynakça açısından genişletilmesi suretiyle üretilmiştir.

** Doktor, Ceza ve Ceza Muhakemesi

Sorumlu Yazar/Correspondence Author: Fatma Sümer

E-posta/E-mail: fatmasummer@gmail.com 


\section{Giriş}

TCK’nın 312. maddesinde hükûmete karşı suç; "Cebir ve şiddet kullanarak Türkiye Cumhuriyeti Hükûmetini ortadan kaldırmaya veya görevlerini yapmasını kısmen veya tamamen engellemeye teşebbüs eden kimseye ağırlaştırılmış müebbet hapis cezası verilir” ifadesiyle kaleme alınmıştır.

Hükûmete karşı suçun işlenmesiyle, cebir kullanılarak siyasi iktidarın devre dışı bırakılması, el değiştirmesi veya bazı faaliyetlerinin engellenmesi amaçlanmaktadır. Bu özellikleri dolayısıyla hükûmete karşı suçun siyasi bir suç olduğu açıktır. Bununla beraber siyasi suçun neyi ifade ettiği konusunda doktrinde bir fikir birliği mevcut olmadığı için ${ }^{1}$ çalışmamızda hükûmete karşı suçun siyasi suç olma niteliğinin genel kabul gören eğilimler çerçevesinde değerlendirilmesi gerekmektedir.

Yargı süreçleri açısından geri vermenin temel amacı, suç işleyen kişinin başka bir ülkeye kaçarak cezasız kalmasının önlenmesidir ${ }^{2}$. Bununla beraber suçun siyasi suç sayılması, siyasi suçluların iade edilemeyeceği yönünde genel bir ilkeyeyi gündeme getirmektedir. Suçun işlenme biçimi ise bu hususta çeşitli istisnaların tartışılmasına olanak sağlar.

Siyasi suçlar söz konusu olduğunda uygulama alanı bulan iki önemli uluslararası sözleşme mevcuttur. 1957 yılında ihdas edilen SİDAS 3 , siyasi suçlar bakımından geri vermenin uygulanmayacağına dair bazı düzenlemeler içermektedir ${ }^{4} .1977$ tarihli olan TÖDAS ${ }^{5}$ ise geri verme ve karşılıklı adli yardım talepleri bakımından siyasi suçlara ilişkin düzenlemelere yer verirken, terör metotlarıyla işlenen fiiller bakımından istisnalar getirmektedir. Ülkemizde 2016 yılında yürürlüğe giren 6706 sayılı Cezai Konularda Uluslararası Adli İş Birliği Kanunu ${ }^{6}$ ise siyasi suçluların, Türkiye’den iadesinin talep edildiği durumlarda uygulama alanı bulabilecek bazı düzenlemeler ihtiva etmektedir.

Geri verme, hukuki niteliğinde, uluslararası adli yardımlaşma özelliğinin ön plana çıktığı bir kurumdur ${ }^{7}$. Kurumun, esasen egemenlik kavramıla da ilişkisi mevcuttur ${ }^{8}$. Çalışmamız ise geri vermenin hukuki yönünü ele almak suretiyle, bir siyasi suç olan, bununla beraber cebir ve şiddet kullanılarak işlenebilen hükûmete karşı suçun geri verme kurumu açısından değerlendirilmesini amaçlamaktadır. Bu sebeple aşağıda geri verme kurumu ve siyasi suçların geri verme kurumu karşısındaki durumu açıklandıktan sonra hükûmete karşı suçun, siyasi suç olma niteliği ve bu kurum bakımından karşılı̆̆ı değerlendirilecektir.

1 Bkz.: Hasan Sınar. “Siyasi Suç Üzerine Bir İnceleme”. İÜHFM. C.: LVIII, S.: 1-2, 2000, s. 53.

2 Bkz.: Kayıhan İçel, Süheyl Donay, Karşılaştırmalı ve Uygulamalı Ceza Hukuku, İstanbul:Beta, 1987, s. 202.

3 Suçluların İadesine Dair Avrupa Sözleşmesi, R.G., 26.11.1959/10365.

4 Bkz.: Kayıhan İçel. Ceza Hukuku Genel Hükümler. İstanbul:Beta, 2018, s. 190. Bu Sözleşme öncesinde ilk olarak İngiltere'de siyasi suçlarda iadenin uygulanmayacağı kabul edilmiştir. Kuralın kodifikasyona konu edilmesi ise ilk olarak Belçika'da 1833 yılında gerçekleşmiştir. Bir uluslararası anlaşmada ise ilk kez 1834 tarihli Fransa-Belçika Antlaşmasında düzenlenerek yer almıştır. Eralp Özgen. Suçluların Geri Verilmesi, Ankara: Ankara Üniversitesi Hukuk Fakültesi Yay., 1961, s. 81; Mehmet Emin Artuk, Ahmet Gökcen, Mehmet Emin Alşahin, Kerim Çakır, Ceza Hukuku Genel Hükümler, Yenilenmiş Gözden Geçirilmiş 14. Baskı, Ankara: Adalet Yay., 2020, s. 1136.

5 Terörizmin Önlenmesine Dair Avrupa Sözleşmesi, R.G., 27.10.1980/17145.

6 R.G. $05.05 .2016 / 29703$.

7 İçel, Genel Hükümler, s. 180.

8 Bkz.: İçel, Genel Hükümler, s. 180. 


\section{GENEL OLARAK GERI VERME KURUMU}

Geri verme; "suçu işlediği Devletten başka bir Devletin ülkesinde bulunan veya oraya kaçmış bir sanık veya hükümlünün, yargılanmak veya cezasını infaz ettirmek üzere "yargılama veya infaza" yetkili Devlete geri verilmesi” anlamına gelmektedir ${ }^{9}$. Masumiyet karinesi gereği kişinin suçlu olabilmesi için yargı organları tarafından hakkında hüküm verilmesi gerekir. Bununla beraber iade kurumu, sadece haklarında hüküm verilmiş olan kişiler bakımından değil, yargılanacak olan kişiler açısından da uygulama alanı bulabilmektedir. Bu sebeple söz konusu kurum literatürde suçluların geri verilmesi veya iadesi ifadeleriyle karşılanıyor olsa da kanaatimizce de kavramı, iade veya geri verme şeklinde ifade etmek daha doğru olur ${ }^{10}$.

Geri verme kurumu, mülga TCK’nun 9. maddesinde ${ }^{11}$ ve ikili anlaşmalarla düzenlenmişti. 7376 sayılı Kanunla onaylanan Suçluların Geri Verilmesi Avrupa Sözleşmesi ile ikili anlaşmaların çoğu ilga edilmişti. Fakat bu dönemde Sözleşmeye taraf olmayan devletlerle yapılan ikili anlaşmalar ve mülga TCK m. 9 halen uygulama alanı bulmaktayd ${ }^{12}$.

5237 sayılı TCK'da ise kurum TCK'nın 18. maddesinde yer almaktaydı ${ }^{13}$. Bu hüküm, ülkemizde 2016 yılında yürürlüğe giren 6706 sayılı Cezai Konularda Uluslararası Adli İş Birliği Kanunu ile ilga edilmiştir. Türkiye’ye yapılacak taleplerde uygulanacak hükümler artık bu Kanunda yer almaktadır.

9 Bkz.: İçel, Donay, s. 201.

10 Bkz.: İçel, Genel Hükümler, s. 186; İçel, Donay, s. 202.

11 Mülga 765 sayılı TCK’nun 9. maddesinde yer alan düzenleme şu şekilde kaleme alınmıştı:

"Bir cürümden dolayı bir Türkün ecnebi devletlere iadesi talebi devletçe kabul olunamaz.

Siyasi veya ona murtabıt cürümlerden dolayı bir ecnebinin ecnebi devletlere iadesi talebi devletçe kabul edilemez.

Ecnebi devletçe vukubulan iade talebi üzerine istenilen kimsenin Türkiye’de bulunduğu mahal mahkemei asliyesince tabiiyeti ve cürmünün mahiyeti hakkında bir karar verilmesi lazımdır.

Türk tebaasindan olduğu yahut cürmünün siyasi ve askeri veyahut bunlara murtabıt cürümlerden bulunduğu mahkemece sabit olanlarm iadesi talebi kabul olunamaz.

Ecnebi olduğuna ve cürmünün adi ceraimden bulunduğuna karar verilen kimsenin iadesi talebi hükûmetçe kabul olunabilir. İadesi talep ve kabul olunan kimse hakkında mahalli müstantikliğince tevkif müzekkeresi verilebilir”.

12 Bkz.: İçel, Donay, s. 203.

135237 sayılı TCK’nun mülga 18. maddesi şu şekilde kaleme alınmıştı:

"(1) Yabancı bir ülkede işlenen veya işlendiği iddia edilen bir suç nedeniyle hakkında ceza kovuşturması başlatılan veya mahkûmiyet kararı verilmiş olan bir yabancı, talep üzerine, kovuşturmanın yapılabilmesi veya hükmedilen cezanın infazı amacıyla geri verilebilir. Ancak, geri verme talebine esas teşkil eden fiil;

a) Türk kanunlarına göre suç değilse,

b) Düşünce suçu veya siyasî ya da askerî suç niteliğinde ise,

c) Türkiye Devletinin güvenliğine karşı, Türkiye Devletinin veya bir Türk vatandaşının ya da Türk kanunlarına göre kurulmuş bir tüzel kişinin zararına işlenmişse,

d) Türkiye'nin yargılama yetkisine giren bir suç ise,

e) Zamanaşımına veya affa uğramış ise,

Geri verme talebi kabul edilmez.

(2) Uluslararası Ceza Divanına taraf olmanın gerektirdiği yükümlülükler hariç olmak üzere, vatandaş suç sebebiyle yabancı bir ülkeye verilemez.

(3) Kișinin, talep eden devlete geri verilmesi hâlinde görüşleri nedeniyle kovuşturulacağına veya cezalandırılacağına ya da işkence ve kötü muamaleye maruz kalacağına dair kuvvetli șüphe sebepleri varsa, talep kabul edilmez.

(4) Kişinin bulunduğu yer ağır ceza mahkemesi, geri verme talebi hakkında bu madde ve Türkiye’nin taraf olduğu ilgili uluslararası sözleşme hükümlerine göre karar verir. Bu karara karşı temyiz yoluna başvurulabilir.

(5) Mahkeme geri verme talebinin kabul edilebilir olduğuna karar verirse, bu kararın yerine getirilip getirilmemesi Bakanlar 
Geri vermede aranan bazı koşullar mevcuttur ${ }^{14}$. Bu koşullar gereği geri verme konusu olan fiilin her iki devletin kanunlarında suç sayılması gerekir. Şayet Türkiye’den talepte bulunulduysa fiil Türkiye’nin yargı yetkisine girmiyor olmalıdır. Suç, zamanaşımına ya da affa uğramamış olmalıdır. Şayet geri verme talebi yargılama amacıyla yapılmış ise, yargılanacak suç hakkında kesin hüküm bulunmamalıdır. Suçun düşünce suçu, siyasi suç ya da askeri suç niteliği taşımaması gerekir. Ayrıca "Vatandaş geri verilmez" kuralı gereği fail talep edilen devletin vatandaşı olmamalıdır.

\section{GERI VERME KURUMU AÇISINDAN SIYASI SUÇLULARIN DURUMU}

\section{A. SIYASI SUÇUN TANIMI}

Siyasi suç kavramı, devletle özdeşleşen ve tarihsel olarak devletin iç ve dış güvenliğine karşı işlenen suçların cezalandırılması sürecinde ortaya çıkmış olan bir kavramdır ${ }^{15}$. Hangi suçların siyasi suç sayılacaklarının belirlenmesinde dikkate alınacak kriterler bakımından doktrinde görüş birliği mevcut değildir ${ }^{16}$. Uluslararası mevzuatta ise siyasi suçun mahiyetini belirleyecek ortak bir tanım bulunmamakla beraber bu alanda sınırlayıcı hükümler getirilmesi yoluyla hangi suçun siyasi suç sayılamayacağının belirtildiği, bu suretle siyasi suçların alanının daraltılması yoluna gidildiği görülmektedir ${ }^{17}$.

Mukayeseli hukukta siyasi suç kavramı genellikle tanımlanmamaktadır. Ülkelerin bu konudaki yaklaşımı; siyasi suçu tanımlamamak, siyasi suçları tanımlamamakla beraber siyasi suçları saymak, siyasi suçu tanımlamamak ve saymamak ve fakat anlatmak ve siyasi suçu tanımlamak olmak üzere dört eğilim çerçevesinde özetlenebilir. Genellikle totaliter devletlerde siyasi suçun mevzuatta tanımlandığı ifade edilmektedir ${ }^{18}$. Örneğin 1930 tarihli İtalyan CK’nın 8. maddesinde “Ceza Kanununun tatbikinde devletin siyasi bir menfaatini veya vatandaşın siyasi bir hakkın ihlal eden suç, siyasi suçtur. Tamamen veya kısmen siyasi saiklerle işlenmiş olan âdi suç da, siyasi sayılır" şeklinde bir siyasi suç tanımı yer almaktaydı $1{ }^{19}$. Mülga 1830 Fransız Ceza Yasası’nda olduğu gibi siyasi suçların ceza kanununda tek tek sayılması ya da bu suçlar için adi suçlardan farklı yaptırımlar öngörülmesi

Kurulunun takdirine bağlıdır.

(6) Geri verilmesi istenen kişi hakkında koruma tedbirlerine başvurulmasına, Türkiye’nin taraf olduğu ilgili uluslararası sözleşme hükümlerine göre karar verilebilir.

(7) Geri verme talebinin kabul edilebilir olduğuna karar verilmesi hâlinde, ayrıca Ceza Muhakemeleri Usulü Kanunu hükümlerine göre tutuklama kararı verilebilir veya diğer koruma tedbirlerine başvurulabilir.

(8) Geri verme hâlinde, kişi ancak geri verme kararına dayanak teşkil eden suçlardan dolayı yargılanabilir veya mahkûm olduğu ceza infaz edilebilir".

14 Bu koşullar için bkz.: İçel, Genel Hükümler, s. 186-196.

15 Bkz.: Sinar, s. 54.

16 Bkz.: İçel, Genel Hükümler, s. 190.

17 Fatih Selami Mahmutoğlu, Serra Karadeniz. Türk Ceza Kanunu Genel Hükümler Şerhi. İstanbul: Beta Yay., 2017, s. 230, d.n. 54.

18 Bkz.: Artuk, Gökcen, Alşahin, Çakır, Genel Hükümler, s. 1132, d.n. 86; Ümit Hassan. "Siyasi Suç Kavramı”. Ankara Üniversitesi SBF Dergisi. Y.: 1971, C.: 26, S.: 1, s. 209-210.

19 Naci Şensoy. “Siyasi Suçlar”. IÜHFM, 1951, C.: XVII, S.: 1-2, s. 57. 
yoluyla bu sayılan ya da farklı yaptırım öngörülen suçların siyasi olduğunun belirtilmesi de bir başka yaklaşımdır ${ }^{20}$.

TCK ise siyasi suçu tanımlamamış ve siyasi suçları saymamış, siyasi suçların belirlenmesini tamamen doktrin ve içtihada bırakmıştır. Bu yaklaşımın karşılaştırmalı hukuktaki eğilim ve düzenlemelere uygun olduğu değerlendirilmektedir ${ }^{21}$.

\section{B. SIYASI SUÇU AÇIKLAYAN TEORILER}

Hangi suçların siyasi suç olduğu konusunda uluslararası mevzuatta ve mukayeseli hukukta birlik bulunmadığı gibi TCK’da da siyasi suçun tanımlanmadığı daha önce belirtilmişti. Bu durumun sonucu olarak doktrinde her yazarın siyasi suç kavramına ilişkin kendi tanımını yaptığ görülmektedir ${ }^{22}$. Yine bu sebeple doktrinde siyasi suçun belirlenmesine yönelik olan çeşitli teoriler ortaya atılmıştır ${ }^{23}$. Bu hususta sıklıkla atıf yapılan iki ana teori mevcuttur ${ }^{24}$.

“Objektif teori” fiilin siyasi suç niteliği taşıyıp taşımadığını suçla korunan hukuki değer doğrultusunda belirlemektedir ${ }^{25}$. Objektif teoriye göre suçla ihlal edilen değer, devletin siyasi düzeni ise siyasi bir suç söz konusu olup, diğer tüm suçlar failin saiki önem taşımaksızın adi suç sayılır ${ }^{26}$. Fiilin işlenmesiyle ihlal edilen menfaat, devletin mevcudiyeti ya da teşkilatına ilişkindir ${ }^{27}$.

"Subjektif teori” ise eylemin, failin saiki doğrultusunda siyasi suç olarak nitelenebileceği yönündeki görüştür ${ }^{28}$. Bu teoriye göre fail siyasi saikle hareket etmediği sürece bir eylem, devletin menfaatlerine zarar verse bile suç siyasi suç sayılamaz ${ }^{29}$. Subjektif teorinin sonucu olarak siyasi saikle işlenen insan öldürme, yağma gibi suçlar da siyasi suç kabul edilmektedir ${ }^{30}$.

Objektif teori siyasi suçun alanını daraltırken, sübjektif teorinin ise objektif teorinin aksine genişletmesi dolayısıyla her iki teori arasında ara yol bulmaya yönelik olarak yeni teoriler ileri sürülmüştür ${ }^{31}$. Bu iki kategorinin eleştirilmesi sonucu ortaya çıkan karma teoriye göre, her iki kategorinin özelliklerini taşımak suçun siyasi suç sayılması bakımından zorunludur ${ }^{32}$.

20 Şensoy, s. 57; Sinar, s. 59.

21 Bkz.: Sinar, s. 59.

22 Mahmut Koca, İlhan Üzülmez, Türk Ceza Hukuku Genel Hükümler, Gözden Geçirilmiş ve Güncellenmiş 13. Baskı, Ankara: Seçkin Yay., 2020, s. 859. Doktrinde yapılan bir tanım, siyasi suçu; "Bireylerin siyasi iktidarı kullanırken ya da bu iktidarı elde etmek veya buna etkili olmak için giriştikleri faaliyetlerde işledikleri hukuka aykırı fiillerin bütünü” olarak ifade etmektedir. Bkz.: Köksal Bayraktar. Siyasal Suç. İstanbul: Fakülteler Matbaası, 1982, s. 65. Bazı tanım örnekleri için bkz.: Hassan, s. $211-212$.

Siyasi suçları açıklayan görüşler için bkz: Artuk, Gökcen, Alşahin, Çakır, Genel Hükümler, s. 1133-1136.

Sinar, s. 59.

25 Koca, Üzülmez, s. 860; Sinar, s. 59.

Artuk, Gökcen, Alşahin, Çakır, Genel Hükümler, s. 1133; Koca, Üzülmez, s. 860.

Bkz.: Şensoy, s. 57.

Sınar, s. 60; Artuk, Gökcen, Alşahin, Çakır, Genel Hükümler, s. 1133; Koca, Üzülmez, s. 860; Şensoy, s. 57.

Bkz.: Sinar, s. 60.

Bkz.: İçel, Genel Hükümler, s. 190.

Bkz.: Sinar, s. 60.

Bkz.: Sinar, s. 60. 
Siyasi suçun belirlenmesi bakımından kabul gören bir başka ayrım, Türk doktrininde de karşılaşılan tam ve nisbi siyasi suçlar sınıflandırmasıdır ${ }^{33}$. Tam siyasi suçlarla doğrudan devletin anayasası ile belirlenen siyasal düzenine ve bireylerin siyasi hak ve özgürlüklerine müdahale eden suçlar ifade edilmektedir ${ }^{34}$. Bu suçlar, siyasi iktidarı ve anayasal düzeni hedef alırlar ${ }^{35}$. Nisbi siyasi suçlar ise adi nitelikteki suçların siyasi saikle işlenmesini ifade $e^{2}{ }^{36}$. Dolayısıyla nisbi siyasi suçlar, siyasi saikle işlenmelerine rağmen adi bir suça da yol açar. Nisbi siyasi suçlar, murtabit ya da bağlı ve muhtelit ya da karma siyasi suçlar olarak ayrılmaktadır. Murtabit siyasi suç, işlenecek veya işlenmekte olan bir siyasi suçla nedensellik bağı bulunan suçu; muhtelit siyasi suç ise adi bir suçun siyasi saikle işlenmesini ifade etmektedir ${ }^{37}$. Siyasi suçun işlenmesi için gerçekleştirilen hazırlık hareketi adi suç teşkil edebilir. Örneğin siyasi suçun işlenmesi için ihtiyaç duyulan paranın, hırsızlık yapılarak elde edilmesi halinde murtabit siyasi suç mevcuttur ${ }^{38}$. Siyasi saikle işlenen bir adi suç, örneğin Cumhurbaşkanına suikast suçu ise bir muhtelit siyasi suçtur ${ }^{39}$. Görüldüğü üzere bir eylem siyasi saik taşımasının yanı sıra adi bir suç da teşkil ettiği veya adi bir suç aracıllğ̆ıla işlendiği takdirde nisbî siyasi suç olarak adlandırılmaktadır.

Doktrinde adi nitelikteki bir suçun ihtilat ya da irtibat dolayısıyla siyasi nitelik taşıyıp taşıyamayacağı konusunda sübjektif teoriye üstünlük tanıyarak failin saikinin esas alınması gerektiğini savunan bir görüş mevcuttur ${ }^{40}$. Ancak bu görüşün savunucuları tarafından da prensip olarak sübjektif teori kabul edilse de somut olay gözetilerek suçun işleniş tarzının dikkate alınması gerektiğinin belirtildiğine dikkat çekilmelidir ${ }^{41}$. Yargıtayın siyasi suçun varlığını tespite yönelik yaklaşımı da faillerin saikini esas almak yönündedir ${ }^{42}$.

\section{GERI VERME KURUMU AÇISINDAN SIYASI SUÇLULARIN DURUMU}

\section{Genel Olarak}

Uluslararası hukukta, siyasi suçluların iade edilmeyeceği, genel bir ilke olarak kabul edilmektedir ${ }^{43}$. $\mathrm{Bu}$ ilke; uluslararası hukuktaki devletin içişlerine karışmama prensibi dolayısıyla iade talep edilen

33 Artuk, Gökcen, Alşahin, Çakır, Genel Hükümler, s. 1147. Bu ayrım doktrinde "mutlak ve göreceli siyasal suçlar" (Sınar, s. 61) ve sırf ve nisbî siyasi suçlar (Hassan, s. 215; Şensoy, s. 58) ifadeleriyle de yer almıştır.

34 Koca, Üzülmez, s. 860.

35 Bkz.: İçel, Genel Hükümler, s. 190.

36 Bkz.: İçel, Genel Hükümler, s. 190.

37 Tanımlar için bkz.: Artuk, Gökcen, Alşahin, Çakır, Genel Hükümler, s. 1147 vd; Şensoy, s. 59.

38 Bkz.: İçel, Genel Hükümler, s. 190.

39 Sinar, s. 63.

40 Bkz.: Şensoy, s. 60-61.

41 Bkz:: Şensoy, s. 61.

42 Bkz.: Sinar, s. 68.

43 Tarihsel süreçte iade prosedürlerinin 18. yüzylla kadar sadece siyasi suçlular bakımından uygulandığı, 19. yüzyıl itibarıyla Fransız İhtilali sonrasında yaygınlaşan değerlerin de etkisiyle siyasi suçların iade müessesesinin dışında bırakıldığı görülmektedir. Bkz.: Şensoy, s. 54. Bununla beraber özellikle terör olgusu, siyasi suçlara ilişkin yaklaşımı tekrar değiştirmiştir. Detaylı bilgi için bkz.: Sınar, s. 56-58. 
devletin, talep eden devletin içişlerine yönelik bir tavır almak istememesinin ve siyasi suçların kamu düzenine verdiği zararın belirlenmesinde adi suçlarda olduğu gibi sosyal ve ahlaki yönden hüküm vermenin kolay olmamasının bir sonucudur. Zira bazen siyasi bir suç işlemenin, zorba bir rejime karşı başvurulabilecek tek çare olabileceği değerlendirilmektedir ${ }^{44}$. Muhtemelen bu görüşle de bağlantılı olarak iade kurumunun hukuki özelliği, suçun siyasi bir suç olup olmadığıyla doğrudan ilgilidir $^{45}$. Failin işlediği suçun bir siyasi suç olması, uluslararası hukukta sığınma hakkının varlığına delalet eder ${ }^{46}$.

Siyasi suç, suçun saik ve hukuki değeri esas alınarak belirlenirken, fiili göz ardı eden bir düzenleme olarak ortaya çımmaktadır. Bu sebeple zamanla siyasi suç olarak kabul edilen bazı fiiller bakımından cezasızlı̆̆ın söz konusu olması halinde toplumsal adalet duygusunun açıkça zedelendiği değerlendirilerek, bu suçların yaptırımsız kalması engellenmek istenmiştir. Uluslararası hukukta siyasi suçlar bağlamında uygulama alanı bulan iki önemli uluslararası sözleşme mevcuttur. Anayasanın 90/son fikrası dolayısıyla iç hukuk hükmünde olan bu Sözleşmelerde önce siyasi suçlarda geri vermenin mümkün olmadığı düzenlenmiş, ardından fiil gözetilerek istisnalar oluşturulmuştur. Bu Sözleşmelerin ilki SİDAS’tır. Tarafları açısından belirli koşullarda karşılıklı iade yükümlülüğü doğuran SİDAS’ın 3/1. maddesi, siyasi suçları ve siyasi suçlarla murtabit filleri kapsamakta ve bu tür fiillere ilişkin iade taleplerinin kabul edilmeyeceğini düzenlemektedir ${ }^{47}$.

SİDAS’a taraf olan ülkeler arasında iadeye ilişkin uygulama alanı bulması gereken esas kaynak SİDAS'tır ${ }^{48}$. SİDAS’a taraf olan devletler arasında Avrupa ülkelerinin hemen hemen tamamı dışında Ermenistan ve Azerbeycan gibi Avrupa ülkesi olmayan devletler de bulunmaktadır ${ }^{49}$. Sözleşme 28. maddesinde taraf devletlerin kendi aralarındaki ikili anlaşma hükümlerini ilga etmiş̧iir ${ }^{50}$. Ayrıca SIDDAS iade talebinin kişiyi ırk, din, milliyet veya siyasi kanaati dolayısıyla cezalandırmak amacıyla yapıldığı ve fakat talebin adi suçla gerekçelendirildiği durumlarda da iade etmeme kuralının uygulanacağını öngörmektedir (m. 3/2). Bu hüküm siyasi suçluların iade edilemeyeceği prensibiyle uyum içinde bulunduğu gibi, taraf devletin kişiyi siyasi saikle cezalandırmasının da önüne geçmeyi hedeflemektedir. Sözleşmenin m. 3/4 hükmü siyasi suçluların iade edilmemesi kuralına çok taraflı anlaşmalarla istisna getirilebileceğini düzenlemiştir ${ }^{51}$.

Bu konudaki daha yeni tarihli bir Sözleşme olan TÖDAS ise terör boyutu taşıyan fiillerin de siyasi suç olarak değerlendirilerek cezasız kalmalarının önüne geçmeye çalışan bir belgedir. Sözleşmenin 3. maddesinde SİDAS dahil olmak üzere Sözleşme tarafları arasında uygulanan bütün anlaşma ve sözleşme hükümlerinin TÖDAS’la bağdaşmadıkları ölçüde ilga edildiklerine yer verilerek bu durumun gözetilmediği düzenlemelerin uygulanmasının önüne geçilmek istenmiştir.

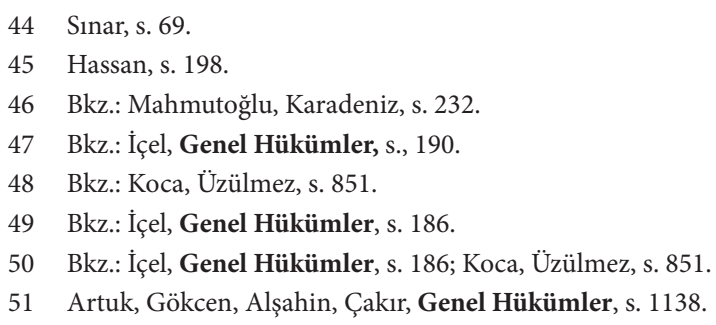


Ülkemize yapılan iadeler bakımından uygulama alanı bulan 6706 sayılı Kanun'da da uluslararası mevzuatla paralel bir biçimde siyasi suçlarda geri vermenin kabul edilmeyeceği düzenlenmiş ve bu husustaki istisnalara yer verilmiştir.

$\mathrm{Bu}$ düzenlemelerin ne anlama geldiği, siyasi suçun istisnalarının incelendiği bölümde açıklık kazanacaktır.

\section{Geri Verme Kurumu Bakımından Siyasi Suçun Istisnaları}

Geri verme kurumuna ilişkin mevzuat gereği nisbi siyasi suç niteliği taşıyan bazı fiillerde geri verme mümkündür ${ }^{52}$. Siyasi suçlarda geri vermeme kuralının istisnaları; Belçika kuralı, terör niteliğindeki fiiller ve soykırım ve savaş suçlarıdır ${ }^{53}$.

BM Milli, Irki, Dini Kitleleri Kısmen veya Tamamen İmha Suçunun Önlenmesi ve Cezalandırılması Hakkında Sözleşme, geri verme ile ilgili 7. maddesinde soykırımın geri verme bakımından siyasi suç sayılamayacağını düzenlemiştir. Soykırım eylemleri Sözleşme’nin 2. maddesinde "milli, etnik, ırki ve dini bir grubu kısmen veya tamamen imha etmek amacı ile grup üyelerinin öldürülmesi, grup üyelerinin bedeni ve akli melekelerinin ciddi surette zarara uğratılması, grubun bedeni varlğının kısmen veya tamamen imhasına neden olacak yaşam şartlarına bilerek tabi tutulmasi, grup içinde doğumları engelleyecek tedbirler alınması, bir grup çocuklarının diğer gruba zorla nakledilmesi" olarak tanımlanmıştır ${ }^{54}$. Benzer tanımlar Eski Yugoslavya ve Ruanda Savaş Suçluları Mahkemeleri ve Uluslararası Ceza Mahkemesi Statüsünde de mevcuttur ${ }^{55}$.

Belçika kuralı ve terör mahiyeti taşıyan fiiller suç tipiyle alakalı olarak uygulama alanı bulabileceği için aşağıda bu iki istisna açıklanacaktır.

\section{a. Belçika Kuralı}

Belçika Kuralı, 1854 yılında Fransız kralı Napolyon III’e düzenlenen bir suikast sonrasında gelişen bir içtihada dayanmaktadır ${ }^{56}$. Söz konusu olay Belçika adli makamları önünde tartışma konusu edilmiş ve Belçika Temyiz Mahkemesi 12 Mart 1855 tarihli bir kararla devlet başkanlarına karşı işlenen

52 Bkz.: Iç̧el, Genel Hükümler, s. 191.

53 Bkz: İçel, Genel Hükümler, s. 191 vd.

54 İçel, Genel Hükümler, s. 193.

55 Bkz:: İçel, Genel Hükümler, s. 193. Eski Yugoslavya Ağır Ceza Mahkemesi Statüsü’nün 4. maddesinde yer alan düzenleme için bkz.: "Updated Statute of the International Criminal Tribunal for the Former Yugoslavia. E.T.: 30.05.2021. https://www.icty.org/x/file/Legal\%20Library/Statute/statute_sept09_en.pdf, s. 5 ve 6. Ruanda Savaş Suçları Mahkemesi Statüsü’nün 2. maddesinde yer alan düzenleme için bkz.: "Statue of the International Tribunal For Rwanda". E.T.: 30.05.2021. https://legal.un.org/avl/pdf/ha/ictr_EF.pdf, s. 43. Uluslararası Ceza Mahkemesi Statüsünün 6. maddesinde yer alan düzenleme için bkz.: "Roma Statue of the International Criminal Court". E.T.: 30.05.2021. https://www.icc-cpi. int/resource-library/documents/rs-eng.pdf, s. 3.

Bkz.: Artuk, Gökcen, Alşahin, Çakır, Genel Hükümler, s. 1136-1137. 
öldürme suçlarının siyasi suç sayılamayacağına hükmetmiştir ${ }^{57}$. Bu konu meclis gündemine de gelmiş ve "yabancı bir devlet reisinin şahsına veya ailesi efradına karşı yapılan suikast, bir cinayet, katil veya bir zehirleme fiili ise, ne siyasi suç ve ne de böyle bir suça murtabit suç olarak telakki edilebilecektir" ifadesiyle kanunlaşmıştır ${ }^{58}$.

Siyasi suçlarda iade taleplerinin kabul edilmeyeceğini düzenleyen SİDAS, m. 3/3 düzenlemesinde Belçika Kuralı'na, istisna olarak yer vermiştir. Düzenleme şu ifadeyle kaleme alınmıştır:

"İşbu Sözleşmenin tatbikatı bakımından, bir Devlet Reisinin veya ailesi efradından birinin hayatına kasıt siyasi bir suç sayılmayacaktır”.

Belçika kuralı, görevde olan devlet başkanı bakımından uygulama alanı bulur. Doktrinde bu kuralın hükûmet başkanını kapsamadığ ${ }_{1}$ ifade edilmektedir ${ }^{59}$. Bu kural, yaşam hakkının herkes için kutsal olduğu gerekçesiyle eleştirilmektedir ${ }^{60}$.

\section{b. Terör Niteliğindeki Fiiller}

Terörizmin önlenmesine dair sözleşmeler terör niteliğindeki fiilleri siyasi suçlarda geri vermeme kuralının istisnaları arasında değerlendirmektedir ${ }^{61}$. Bu konuda kapsayıcı nitelikte düzenlemeler içermekte olan TÖDAS, başlangıç kısmında terörizmin önlenmesinde suçluların iadesinin “özellikle etkili bir çare olduğu” inancına yer vermiştir. TÖDAS, 1. maddesinde terör eylemlerinin siyasi suç, siyasi suça murtabit suç veya siyasi nedenle işlenmiş suç sayılamayacağını düzenlemiştir. Bu suretle terör eylemlerinin siyasi suçlarda iadenin uygulanmayacağı kuralının istisnasını teşkil ettiğini açıkça düzenlemektedir ${ }^{62}$.

Sözleşmede terör eylemleri;

"16 Aralık 1970 tarihinde La Haye'de imzalanan uçakların kanun dışı yollarla ele geçirilmesinin önlenmesine ilişkin sözleşmenin kapsamına giren suçlar;

23 Eylül 1971 tarihinde Montreal’de imzalanan sivil havacıliğın güvenliğine karşı kanun dışı eylemlerin önlenmesine ilişkin Sözleşmenin kapsamına giren suçlar;

Diplomatik ajanlar dahil olmak üzere uluslararası bir himayeye tabi olan şahısların hayat, fiziki bütünlüğ̈̈ veya hürriyetine bir saldırıyı kapsayan vahim suçlar; adam kaldırma, rehin alma veya gayri kanuni hürriyeti tahdit eden suçlar;

57 Bkz.: Artuk, Gökcen, Alşahin, Çakır, Genel Hükümler, s. 1136, d.n. 103.

58 Artuk, Gökcen, Alşahin, Çakır, Genel Hükümler, s. 1136.

59 İçel, Donay, s. 221.

60 Bkz.: Artuk, Gökcen, Alşahin, Çakır, Genel Hüikümler, s. 1137.

61 Mahmutoğlu, Karadeniz, s. 232. Uluslararası sözleşmelerle terör hareketlerinin cezalandırılmalarına ilişkin gelişim süreci için bkz.: Bayraktar, s. $166 \mathrm{vd.}$

62 Sinar, s. 73. 
Şahısların hayatı için tehlike teşkil ettiği ölçüde bomba, el bombası, roket, otomatik ateşli silah veya bombah mektup veya koli kullanmak suretiyle işlenen suçlar ve

Sayılan suçlardan birini işlemeye teşebbüs veya böyle bir suçu işleyen veya işlemeye teşebbüs eden bir şahsın fiiline suç ortağı olarak iștirake ilişkin suçlar.",

olarak sinıflandırılmaktadır (m.1).

Bu düzenleme dışında TÖDAS taraf devletlere 1. madde çerçevesinde olmadığı halde şahısların hayat, vücut bütünlüğü veya hürriyeti aleyhine işlenen bir şiddet eylemi ya da vahim bir suçu siyasi suç, siyasi suça murtabit suç veya siyasi nedenle işlenmiş suç saymama konusunda takdir yetkisi tanınmıştır. Mülkiyet aleyhine işlenen suçlar da toplu bir tehlike teşkil ettikleri durumlarda bu takdir yetkisi çerçevesindedir (m. 2).

Daha önce de belirtildiği üzere SİDAS’’n $\mathrm{m}$. 3/1 düzenlemesi siyasi suçlar ve siyasi suçlarla murtabit fiiller bakımından geri verme taleplerinin kabul edilmeyeceğine yer vermektedir. TÖDAS’n 1 . maddesinde ise sayılan fiillerin siyasi suç ya da siyasi suçla murtabit suç sayılmaları suretiyle geri verme taleplerinin reddedilmesinin mümkün olmadığı düzenlenmiştir. Örneğin şahısların hayatı için tehlike teşkil ettiği ölçüde bomba, el bombası, roket, otomatik ateşli silah veya bombalı mektup veya koli kullanmak suretiyle işlenen bir suç (TÖDAS m. 1/4) siyasi bir suçun hazırlık hareketi olarak işlendiği durumda siyasi suçla murtabit fiil olarak değerlendirilerek SİDAS’n 3/1. maddesi çerçevesinde ele alınamayacaktır. Zira TÖDAS hem yeni tarihli bir düzenlemedir hem de 3. maddesinde SİDAS dahil olmak üzere Sözleșme tarafları arasında uygulanan bütün anlaşma ve sözleşme hükümlerinin TÖDAS’la bağdaşmadıkları ölçüde ilga edildiklerine yer verilmiştir. TÖDAS'la birlikte artık terör eylemleri siyasi suç sayılamamaktadır ${ }^{63}$.

Sözleşmede söz konusu düzenlemelere yer verilmesiyle takdir edilen irade, bu tür fiillerin cezasız kalmaması zaruretidir. Bu sebeple TÖDAS, şayet iade gerçekleşmeyecekse ve suç 1. maddede yer alan durumlardan birine ilişkinse kişinin bulunduğu devlete yargılama yükümlülügü getirmektedir ( $\mathrm{m}$. 6-7). Benzer düzenlemeler karşılıklı adli yardım talepleri bakımından da tekrarlanmıştır ${ }^{64}$.

Ülkemize yapılan iade talepleri bakımından uygulama alanı bulan 6706 sayılı Kanun gereği kişinin siyasi görüşleri gerekçesiyle soruşturma, kovuşturma ya da yaptırıma maruz kalacağı veya işkence ya da kötü muamele göreceğine dair kuvvetli şüphe sebeplerinin bulunması (m. 11/1-b) ve iade talebinin konusu olan fiilin düşünce suçu, siyasi suç veya siyasi suçla bağlı bir fiil olması (m. 11/1-c-1) halinde iade talebi kabul edilmez. Bununla beraber Kanunun 11/1-c-1 maddesinde iade talebinin dayanağını teşkil eden fiilin bütün unsurları, özellikle işlenişs şekli, suçun işlenişinde kullanılan araçların veya

63 Bkz:: Süheyl Donay. “Tedhiş̧̧iliğin Cezalandırılması Hakkında Avrupa Sözleşmesi”, IÜHFM, 43/1-4, Temmuz 2011, s. 420; Bayraktar, s. 174.

64 TÖDAS’n adli yardım taleplerini düzenlediği maddelerinde, adli yardım talebinin bir suçun siyasi suç ya da siyasi suça bağlı suç olduğu gerekçesiyle reddedilemeyeceğine yer verilmiştir. Bununla beraber söz konusu talep, kişinin ırkı, dini, milliyeti, siyasi kanaatleri dolayısıyla yapılıyorsa Sözleşme hükümlerinin yükümlülük teşkil eder şekilde yorumlanamayacağı düzenlenmiştir (TÖDAS m. 5). Ayrıca adli yardımı konu edinen ve TÖDAS’la bağdaşmayan tüm anlaşma hükümleri TÖDAS’ın 8. maddesiyle ilga edilmiştir. 
ortaya çıkan sonuçların ağırlığı dikkate alınarak fiilin siyasi suç sayılmamasının mümkün olduğu düzenlenmiştir. Soykırım ve insanlığa karşı suçlar siyasi suç olarak kabul edilmez (m. 11/2). Bu düzenlemeler uluslararası normlarla paralel mahiyet taşımaktadır.

\section{HÜKÛMETE KARŞI SUÇUN SIYASI SUÇ OLMA NITELIĞi}

Hükûmete karşı suçun siyasi iktidarı hedef alan bir suç tipi olması, başka bir ülkede bulunan sanık ya da hükümlünün iadesinde olumsuz şartı gerçekleştirip gerçekleştirmediği bakımından değerlendirilmesi gereken bir meseledir. Esasen hükûmete karşı suçun, siyasi bir suç olup olmadığı hususunda doktrinde bir tartışma mevcut değildir. Bununla beraber geri verme kurumuna ilişkin düzenlemelerin siyasi suçlarda geri vermenin mümkün olmadığına ilişkin genel bir kabule dayanmaları ve bu kabulün istisnalarına yer vermeleri suç tipinin siyasi suçu açıklamaya yönelik olan teoriler çerçevesinde ele alınmasını gerektirmektedir.

Siyasi suçu açıklayan iki temel akımın söz konusu olduğu; bu akımlardan objektif teorinin suçla korunan hukuki değerden yola çıktığ ${ }^{65}$; subjektif teorinin ise failin saikini esas aldığ ${ }_{1}^{66}$ daha önce belirtilmişti. Bu iki kategorinin eleştirilmesi suretiyle ortaya çıan karma teoriye göre siyasi suçlarda hem suçun koruduğu hukuki değer hem de failin saiki siyasi niteliktedir ${ }^{67}$. Bu hususta yapılan bir diğer ayrım ise fiilin de gözetildiği tam ve nisbi siyasi suç ayrımıdır. Tam siyasi suçlarla doğrudan devletin anayasası ile belirlenen siyasal düzenine ve bireylerin siyasi hak ve özgürlüklerine müdahale eden suçların kastedildiği ${ }^{68}$; nisbi siyasi suçların ise adi nitelikteki suçların siyasi saikle işlenmesini ifade ettiği üzerinde daha önce durulmuştu ${ }^{69}$.

$\mathrm{Bu}$ ayrımlar çerçevesinde suçun siyasi suç olduğunun tespitinde; suçla korunan hukuki değer ve failin saiki; geri vermenin istisnası olarak ise fiil belirleyicidir.

Hükûmete karşı suçla korunan hukuki değer; "milli irade" olgusu ve bu olgunun gerçekleşme usulü olan "demokrasi"dir ${ }^{70}$. Suç tipinin Kanundaki yerinden yola çıkılarak da bu hususta bazı değerlendirmelerde bulunulabilir. Hükûmete karşı suç, TCK’nın “Millete ve Devlete Karşı Suçlar ve Son Hükümler" başlıklı dördüncü kısmında "Anayasal Düzene ve Bu Düzenin Isşleyişine Karşı Suçlar” başlıklı beşinci bölümde yer alır. Anayasal düzenin bir unsuru olan hükûmet, devlete ait

65 Sinar, s. 59.

66 Sinar, s. 60; Artuk, Gökcen, Alşahin, Çakır, Genel Hükümler, s. 1133.

67 Bkz.: Sinar, s. 60.

68 Koca, Üzülmez, s. 860.

69 Bkz.: İçel, Genel Hükümler, s. 190.

70 Bkz.: İzzet Özgenç, Suç Örgütleri, Gözden Geçirilmiş ve Genişletilmiş 13. Bası, Ankara: Seçkin Yay., 2020, s. 274 ve s. 294. Suçla koruduğu hukuki değer, Parlar’a göre; "hükûmetin "Anayasa kurallarına uygun biçimde görevini yerine getirebilmesi imkanının korunması” (Ali Parlar, Türk Ceza Kanunu Şerhi, Cilt: II, Ankara: Bilge Yayınevi, 2015, s. 3100); Özek’e göre; "siyasi iktidar fonksiyonlarının” korunması (Çetin Özek, Siyasi İktidar Düzeni ve Fonksiyonları Aleyhine Cürümler (TCK m. 146-151, 168-173), İstanbul Üniversitesi Yay. No: 1251, Hukuk Fakültesi No.: 267, İstanbul: Cezaevi Matbaası, 1967, s. 199); Hafızoğulları, Özen’e göre; “...muhtemel cebri davranışlara karşı hükûmetin esenliğinin, görevinde engellenmemesinin sağlanmasına ilişkin kamusal yarar” (Bkz.: Zeki Hafızoğulları, Muharrem Özen. Türk Ceza Hukuku Özel Hükümler Millete ve Devlete Karşı Suçlar. Ankara: US-A Yay., 2016, s. 387) dır. 
bir iktidarı kullanmaktadır. Yürütme organının içinde olan bu iktidar, yürütmenin idari kısmının dışında kalmaktadır. Bu anlamıyla hükûmet siyasi iktidarı karşılayan bir kavramdır ${ }^{71}$. Ülkemizde hükûmet, cumhurbaşkanının devlet başkanlığını demokratik seçimlerle kazanması suretiyle ortaya çıkmaktadır. Anayasal düzenin temel gerekliliği olan ve demokrasiyi kuran prensipler, iktidarın işbaşına gelmesi, görevini yerine getirmesi ve iktidarının sona ermesine ilişkin olarak belirlenen usullerin dışına çıkılmaması suretiyle vücut bulur.

Demokrasi bir yönetilme tercihidir. Her ne kadar Yargitay bir kararında siyasi iktidarın devleti meydana getiren dinamik unsur olmasından hareketle, bir devletin mevcudiyet ve devamının siyasi iktidarın himayesine bağlı olduğunu belirtmiş ise $\mathrm{de}^{72}$ suç tipiyle esasen devletin yönetilme tercihi korunmaktadır. Demokrasiyi koruma özelliği dolayısıyla hükûmete karşı suç, devletin güvenliğine karşı suçlardan farklıdır. Bu farklılık, darbe ve müdahalelerin genellikle iktidarın el değiştirmesini hedeflemesinden anlaşılabilmektedir ${ }^{73}$. Suç pratikte devlet karşıtlığı ya da devleti ortadan kaldırma gibi düşüncelere sahip olan kişiler tarafından değin aksine statükocu ve fakat devletin işleyişini kendi inisiyatiflerinde tutmak isteyen kişilerce işlenmektedir.

Hükûmete karşı suç failinin saiki; Doktrinde, Kanun maddesinde açıkça düzenlenmediği için suç tipinde saik bulunmadığı savunulmakta ${ }^{74}$ ve hükûmeti ortadan kaldırma ve görev yapmasını kısmen ya da tamamen engelleme unsurları maddi unsur başlığı altında ele alınmaktadır ${ }^{75}$. Bununla beraber suçun teşebbüs suçu olması sebebiyle bu ifadelerin failin saik ya da amacı olarak değerlendirilmesi gerektiği ancak suçun tamamlanmasi için bu hususun gerçekleşmesinin gerekmediği yönünde bir görüş de mevcuttur ${ }^{76}$. Yargitay'n mülga 765 sayılı TCK döneminde suçun işlenmesinde amaç unsurunun gerçekleşmesini aradığ ${ }^{77}, 5237$ sayılı TCK döneminde ise genellikle suçun "amaca matuf doğrudan genel kastla" işlenebileceğini kabul ettiği görülmektedir ${ }^{78}$. Ankara 5. Ağır C.M. hükûmete karşı suça ilişkin bir kararında hükûmetin ortadan kaldırılması veya görev yapmasının engellenmesinin failin

71 Bkz.: Özek, s. 252.

72 Y.16.C.D., E.: 2015/5829, K.: 2016/4175, T.: 21.06.2016.

73 Kanaatimizce darbe niteliğindeki fiillerin işlenmesinde faillerin, hali hazırda ihtiyaç duyulan Anayasa değişiklikleri bakımından inisiyatifin mevcut iktidara bırakılmaması yönündeki çabaları da rol oynamıştır. Örneğin bir Anayasa değişikliğine ihtiyaç bulunduğu 1980 darbesi öncesinde de dile getirilmiştir. Bkz.: Ergun Özbudun. Türk Anayasa Hukuku. Ankara: Yetkin, 2019, s.44; Kemal Gözler, Türk Anayasa Hukuku, 3. Baskı, Bursa: Ekin Yay., 2019, s. 112 - 113. Bununla birlikte failler bu değişikliği mevcut hükûmet politikasını yürütmekte olan iktidarın inisiyatif ve tercihlerine bırakmamayı tercih etmişlerdir.

74 Bkz:: Doğan Soyaslan, Ceza Hukuku Özel Hükümler, Güncelleştirilmiş 12. Baskı, İstanbul: Yetkin Yay., Ankara, 2018, s. 803.

75 Bkz.: Parlar, C. II, s. 3100-3101.

76 Özgenç, Suç Örgütleri, s. 288-289. Genel kastın yeterli olduğunu savunan bazı yazarlar için bkz.: Özek, s. 267; Osman Yaşar, Hasan Tahsin Gökcan, Mustafa Artuç, Yorumlu-Uygulamalı Türk Ceza Kanunu, Cilt VI, s. 8509.

77 "TCK’nın 499/2. maddesinin ancak ideolojik olmayan ve bir Anayasa değişikliğini de gerektirmeyen siyasi ve sosyal maksatlarla, adam kaçırma filllerine uygulanabilir. Buna karşıllk söz konusu hüküm, ideolojik nedenlerle, başka bir deyimle Anayasa'yı zorla değiştirmeyi amaçlayan düşünce ile adam kaçırma fiillerini kapsamaz. Bu fillerin ancak TCK'nın 146. maddesinin 1. fikrası kapsaminda düşünülmesi zorunludur". Bkz.: Y. 9. CD., 20.2.1975, 2-6/2, Savaş, Mollamahmutoğlu, II, s. 1529. Aktaran Özgenç, Suç Örgütleri, s. 289.

78 Y. 16.C.D., E.: 2018/3136, K.: 2019/1937, T.: 19.03.2019. 16. C.D. bir kararında "genel kastla gerçekleştirilen nihai amaca matuf eylemlerin, hükûmeti ortadan kaldırma veya görevlerini yapmasın kısmen ya da tamamen engelleme amacıla gerçekleştirilmesi” gerektiği ifadelerine yer vermiştir. Y. 16. C.D., E.: 2018/4068, K.: 2019/940, T.: 04.02.2019. 
suçla elde etmek istediği amaç olduğu düşüncesine ve icrasına başlanılan hareketin amaca yönelik tehlike oluşturmaya uygun ve elverişli olması gerektiği hususuna yer vermiştir. Bu yoruma rağmen mahkeme manevi unsuru değerlendirirken suçun oluşmasında belirli bir saik aranmadığını belirtmiştir ${ }^{79}$.

Esasen her fiil bir ya da birden fazla saikle gerçekleştirilir ${ }^{80}$. Bununla beraber saikin ceza hukuku anlamında önem taşıması için Kanun maddesinde unsur veya nitelikli hal olarak yer alması gerekmektedir ${ }^{81}$. İç hukukumuz bakımından önem taşıyan bu tartışma, Kanun maddesinin düzenlenmesindeki teknik bir tercihi ifade etmektedir. Geri verme kurumu bakımından değerlendirildiğinde Kanun maddesinde açıkça saik olarak düzenlenmemiş olan "hükûmeti ortadan kaldırma" ya da "görevlerini yapmasını kısmen veya tamamen engelleme" ifadeleri dolayısıyla failin siyasi saikle hareket ettiği kabul edilmelidir.

Suçla korunan hukuki değerin siyasi iktidara ilişkin olması ve failin siyasi saikle hareket etmesi dolayısıyla suç tipinin gerek objektif teoriye gerekse sübjektif teoriye göre siyasi suç niteliği taşıdığ 1 görülmektedir. Bununla beraber hükûmete karşı suçun siyasi suçlar içerisinde yapıllan tam ve nisbi siyasi suçlar ayrımı bakımından da değerlendirilmesi gerekmektedir.

Hükûmete karşı suçta fiil; cebir ve şiddet kullanılması suretiyle hükûmeti ortadan kaldırmaya veya görevlerini yapmasını kısmen veya tamamen engellemeye teşebbüs edilmesidir. Kanundaki düzenleme çerçevesinde hükûmete karşı suç cebir ve şiddetle işlenmesi mümkün olan bağlı hareketli bir suçtur ${ }^{82}$. Hükûmete karşı suçun ne tür fiillerle işlenebileceğine örnek vermeden önce, şiddet ve cebrin aynı anlama geldiğini belirtmekte fayda görüyoruz ${ }^{83} .5237$ sayılı TCK'da bazı suçlarda bu iki kavram birlikte kullanılmaktadır ${ }^{84}$. Örneğin Kanunun 28. maddesinin kenar başlı̆̆ "cebir ve şiddet, korkutma ve tehdit" olarak kaleme alınmıştır. Bu düzenleme doktrinde eleştirilmekte ve cebrin şiddetle aynı anlama geldiği, korkutmanın ise tehdidin doğal sonucu olarak ortaya çıktığı ifade edilmektedir ${ }^{85}$. Bu yorum sebebiyle cebir ve şiddete Kanun maddesinin başlı̆̆ında aynı anda

79 Bkz.: Ankara 5. Ağır C.M. Dosya No.: 2014/144, Karar No.: 2018/248, Cumhuriyet Savcıllı̆ı Esas No.: 2013/35. T.: 13.4.2018.

80 Bkz:: Turhan Tûfan Yüce. Ceza Hukuku Dersleri Cilt:1. Manisa: Şafak Basım ve Yay., 1982, s. 334.

81 Bkz.: Yüce, s. 334.

82 Aynı yönde bkz.: Yaşar, Gökcan, Artuç, s. 8508. Ayrıca bkz.: Ankara 5. Ağır C.M. Dosya No.: 2014/144, Karar No.: 2018/248, Cumhuriyet Savcılı̆̆ı Esas No.: 2013/35. T.: 13.4.2018. Doktrinde Anayasayı ihlal suçunun serbest hareketli bir suç olduğunu savunan bir yazar bulunmaktadır. Bkz.: Ezgi Aygün Eşitli, "Anayasayı İhlal Suçu”, Ankara Üniversitesi Hukuk Fakültesi Dergisi, C.: 65, S.: 4, 2016, s. 1696.

83 Bu görüş için bkz.: Özgenç, Genel Hükümler, s. 434; İlhan Üzülmez. Yeni Türk Ceza Kanunu’nun Hürriyete Karşı İşlenen Suçlar Sistemi Çerçevesinde Tehdit, Şantaj ve Cebir Suçları. Ankara: Turhan Kitabevi, 2007, s. 45; Özgür Küçüktaşdemir, Türk Ceza Hukukunda Cebir ve Manevi Cebir, Ankara: Seçkin Yayıncıllk, 2012, s. 57.

$84 \mathrm{Bu}$ durumun 765 sayılı TCK döneminin bir alışkanlığı olduğu ifade edilmektedir (Üzülmez, s. 45). Mülga TCK'da suçun unsuru ya da ağırlaştırıcı sebebi olarak düzenlenen "cebir", "tehdit" ve "şiddet" kavramları zaman zaman birlikte ya da ayrı ayrı kullanılmıştır (Yüksel Ersoy. Çalışma Hürriyetine Karşı Suçlar (TCK m. 201 ve 275 sayılı kanunun ilgili hükümleri). Ankara: Ankara Üniversitesi Basımevi, 1973, s. 114). Bu durumun mülga TCK’nun İtalyan CK'dan tercüme edilmesi sırasında terim birliği oluşturulamamasından ve söz konusu dönemde Osmanlı Türkçesi’nde anlamı güçlendirmek amacıyla aynı anlama gelen sözcükleri birlikte kullanma alışkanlığının bulunmasından kaynaklandığı değerlendirilmiştir (Ahmet Gökcen. Halkı Kin ve Düşmanlığa Açıkça Tahrik Cürmü (TCK m. 312/2). Ankara: Liberal Düşünce Topluluğu Yay., 2001, s. 14-15; Üzülmez, s. 42).

Bu konuda bkz.: Özgenç, Genel Hükümler, s. 434. 
yer verilmesinin doğru olmadığ ${ }_{1}$ yönünde bizim de katıldığımız bir görüş de bulunmaktadır ${ }^{86}$. Bu sebeple çalışmamızda sadece cebir kavramını kullanarak devam edeceğiz.

Suçun bağlı hareketli bir suç olmasının sonucu olarak cebir dışındaki bir fiille işlenmesi mümkün değildir. Cebir kullanılmadığı sürece Anayasaya ya da kanunlara aykırı bir fiilin işlenmesi halinde hükûmete karşı suç teşekkül etmeyecektir. Örneğin; hükûmetin bir faaliyetinden vazgeçmesi için kanunsuz gösteri yürüyüşü yapılması cebir kullanılmadığı sürece hükûmete karşı suça sebebiyet vermez. Ancak bu fiil 2911 sayılı Toplantı ve Gösteri Yürüyüşleri Kanununun ${ }^{87} 28$ ve devamı maddeleri çerçevesinde cezalandırılabilir.

Cebir tehdit suretiyle zorlamayı ve fiziki zorlamayı içeren bir üst kavramdır ${ }^{88}$. Tehdidin manevi cebir olarak nitelenmesinin sonucu olarak cebir kavramına tehdidin de dahil olduğu kabul edilmektedir ${ }^{89}$. Bununla beraber maddi ve manevi her türlü cebrin suça sebebiyet vereceği de söylenemez. Fiil ve kullanılan vasıta bakımından bir diğerinden farklı iki hareket olan cebir ve tehdit, iradeyi zorlamaya yönelik olarak aynı olayda birleşebilmektedir ${ }^{90}$. Hükûmete karşı suçun işlenmesinde elverişli sayılabilecek hareketlerin de bu nitelikte oldukları kanaatindeyiz. Alman CK'nda yer alan federal devlete ihanet (m. 81) ve bir eyaletin hükûmetini yetkilerini kullanmamaya ya da belli bir yönde kullanmaya zorlama (m. 105) suçlarında maddi unsur cebir ya da cebir kullanma tehdidi olarak belirlenmiştir. Bu düzenlemenin, tehdidin kanundaki özel düzenleniş biçimlerini de dışladığını ve suç tipindeki elverişli hareketin bu suretle vücut bulduğunu düşünüyoruz.

Siyasi saikle cebir kullanmanın düzenlenmesi suç tipini nisbi siyasi suçlar arasında değerlendirmemize yol açmaktadır. Suç tipinde kullanılan cebir, suçun hazırlık hareketi değil bizzat kendisidir. Bu sebeple suç tipi bir muhtelit siyasi suç niteliğindedir.

\section{GERI VERME KURUMUNUN HÜKÛMETE KARŞI SUÇ BAKIMINDAN INCELENMESi}

Adi bir suçun, siyasi bir saikle işlenmesi suretiyle vuku bulan hükûmete karşı suçun faili, cebir kullanarak hükûmeti ortadan kaldırmaya ya da görev yapmasını kısmen ya da tamamen engellemeye teşebbüs eder. Cebir, hükûmete tesir etmekte ve suçun konusunun hükûmet olduğu, hükûmete karşı suçun Kanun maddesinin gerekçesinde de belirtilmektedir ${ }^{91}$.

Türkiyede hükûmet, uzun zaman başbakan başkanlığındaki Bakanlar Kurulunu ifade etmiştir. 1 Haziran 2005 tarihine değin yürürlükte olan mülga TCK m. 147'de yer alan “icra vekilleri heyeti”ne

86 Bkz.: Artuk, Gökcen, Alşahin, Çakır, Genel Hükümler, s. 583.

87 Toplantı ve Gösteri Yürüyüşleri Kanunu, R.G. 08.10.1953/18185.

88 Bkz.: Küçüktaşdemir, s. 58.

89 Faruk Erem. "Ceza Hukukunda “Cebir” Kavramı". Yargıtay Dergisi. C.: 16, S. 1-2, Ocak-Nisan 1990, s. 94.

90 Manzini, VIII, s. 694. Aktaran Erem, s. 95.

91 Suçun konusu, "kanuni tanımdaki hareketin yöneldiği, suçun üzerinde icra edildiği kişinin fiziki, maddi yapısı veya şey” olarak tanımlanmaktadır (Artuk, Gökcen, Alşahin, Çakır, Genel Hükümler, s. 375. Doktrinde yer alan başka bazı tanımlar için bkz.: Koca, Üzülmez, s. 116). Madde gerekçesinde suçun konusunun "Anayasa düzeninin temel organlarından biri” olan, "Türkiye Cumhuriyeti Devletinin egemenlik unsurunun oluştuğu üç güçten yönetim gücünü temsil eden hükûmet" olduğu ifade edilmiştir. 
karşılık olarak Bakanlar Kurulunun korunduğu yargı kararlarına da yansımışııı92 ${ }^{92}$ Bununla beraber 16 Nisan 2017 tarihli referandumda kabul edilen 21 Ocak 2017 tarih ve 6771 sayılı Anayasa Değişikliği Hakkında Kanun’la hükûmet sistemi bütünüyle değişmiştir ${ }^{93}$.

Cumhurbaşkanlığı Hükûmet Sistemi olarak adlandırılan yeni sistemde yapılan düzenlemeler çerçevesinde Anayasanın 8. maddesiyle yürütme yetki ve görevinin münhasıran cumhurbaşkanına özgülendiği görülmektedir. Bakanlar Kurulu ve başbakanlık kaldırılmış ${ }^{94}$ ve 477 sayılı Kanunla bazı Kanunlarda değişiklik yapılması hakkındaki 698 sayılı $\mathrm{KHK}^{95}$ ile bu iki kurumun tüm yetkileri cumhurbaşkanına devredilmiştir. Bu düzenlemeler karşısında artık Kanunun 312. maddesinde yer alan düzenlemeyle hükûmet, cumhurbaşkanı nezdinde korunmaktadır.

Yeni sistemde hükûmete karşı suçun işlenmesiyle aynı zamanda hükûmet başkanı da olan cumhurbaşkanının iradesi etkilenmektedir. Bu suçun işlenmesinde cebir doğrudan doğruya cumhurbaşkanını hedef alabilir ${ }^{96}$. Bu takdirde siyasi suçluların geri verilmemesi kuralının suç tipiyle ilgili olarak ortaya çıkabilecek ilk istisnası olan ve SİDAS m. 3/3’te de düzenlenen Belçika kuralının, hükûmete karşı suç bakımından uygulama alanı bulması mümkündür.

Belçika kuralı, hali hazırda görev yapmakta olan devlet başkanı için uygulama alanı bulur. Daha önce de ifade edildiği üzere doktrinde bu kuralın hükûmet başkanını kapsamadığı ifade edilmektedir ${ }^{97}$. Bazı uluslararası sözleşmeler ise aksi yöndedir. Örneğin Türkiye’nin ABD, Irak ve İran'la yaptığı ikili anlaşmalarda hükûmet başkanı ve ailesine karşı işlenen suçların da bu kural kapsamına dahil edildiği görülmektedir ${ }^{98}$. Parlamenter sistemin hakim olduğu dönemde ülkemiz için önemli olan bu ayrıma rağmen, Cumhurbaşkanlığı hükûmet sisteminde devlet başkanının aynı zamanda hükûmet başkanı olması, Belçika kuralından yararlanılması konusunda bu tür bir ikilemin doğmasını engellemektedir.

92 Mülga TCK’nın 147. maddesinde ifade edilen icra vekilleri heyetinden kasıt hükûmettir. Hükûmetin Anayasaya göre Bakanlar Kurulunu ifade ettiği hususu parlamenter sistem döneminde verilen yargı kararlarına yansımıştır. Bkz.: Y. 16.C.D., E.: 2016/6690, K.: 2018/604, T.: 08.03.2018; Ankara 5. Ağır C.M. Dosya No.: 2014/144, Karar No.: 2018/248, Cumhuriyet Savcılığı Esas No.: 2013/35. T.: 13.4.2018.

936771 sayılı Türkiye Cumhuriyeti Anayasasında Değişiklik Yapılmasına Dair Kanun, RG: 11.02.2017, 29976.

94 Gözler, Türk Anayasa Hukuku, s. 764.

95698 sayılı KHK, 04.07.2018/30468.

96 Referandum sonrasında suçun konusunda meydana gelen bu değişim, suç tipini TCK’nın 310. maddesinde yer alan Cumhurbaşkanına suikast ve fiili saldırı suçlarıyla benzer hale getirmiştir. TCK’nın 310/1. maddesinde cumhurbaşkanına suikastte bulunmak suçu düzenlenmiştir. Bu düzenleme madde gerekçesinde de belirtildiği üzere kasten öldürme suçuna nazaran özel bir düzenlemedir. Bkz.: Yaşar, Gökcan, Artuç, s. 8494; Hadi Salihoğlu, Ali Parlar, Mustafa Öztürk. Uygulamada Terör Suçları Devlete ve Anayasal Düzene Karşı Suçlar. Ankara: Bilge Yay., 2018, s. 158. TCK m. 310/2'de ise cumhurbaşkanının şahsına karşı gerçekleştirilen ve kasten öldürme ile TCK m. 299'da yer alan cumhurbaşkanına hakaret dışında kalan fiillerin tamamını ifade eden fiili saldırı suçu yer almaktadır. Bkz.: Zeki Hafızoğulları, Özgür Küçüktaşdemir. “Cumhurbaşkanına Suikast ve Fiili Saldırı Suçu”. Prof. Dr. Nevzat Toroslu’ya Armağan. Ankara Üniversitesi Yayınları No.: 459, 2015, s. 573. Hükûmete karşı suç ile Cumhurbaşkanına suikast ve fiili saldırı suçları (TCK m. 310) arasındaki fark, hükûmete karşı suçun cumhurbaşkanını fonksiyonlarından ötürü korumasıdır. Aynı fiil hükûmeti ortadan kaldırmak ya da görev yapmasını engellemek için işlendiği takdirde TCK m. 312 uygulama alanı bulur.

İçel, Donay, s. 221.

98 Bkz.: Bayraktar, s. 143. 
Belçika kuralının uygulanması bakımından cumhurbaşkanına vekalet eden kişilerin durumunun da değerlendirilmesi gerekir. Anayasảnın 104/8. maddesinde cumhurbaşkanının kendi yardımcılarını atayacağı düzenlenmiştir ${ }^{99}$. Bu düzenlemeyle ihdas edilen Cumhurbaşkanı yardımcılığı, ülkemizde daha önce mevcut olmayan bir kurumdur. Anayasanın 106. maddesinin 2. fikrasında iki durumda cumhurbaşkanı yardımcısının cumhurbaşkanına vekalet ederek yetkilerini kullanacağ 1 düzenlenmiştir. Bu durumlar; cumhurbaşkanlığı makamının herhangi bir sebeple boşalması halinde yeni cumhurbaşkanı seçilene kadarki 45 günlük süreç ve cumhurbaşkanının hastalık ve yurt dışına çıkması gibi sebeplerle geçici olarak görevinden ayrılmasıdır. Belçika kuralıyla getirilen istisnanın şahsı değil makamı gözettiği düşüncesiyle makamda vekaleten bulunan kişilerin de bu düzenlemeden yararlanmaları gerektiği kanaatindeyiz ${ }^{100}$.

Hükûmete karşı suç, cumhurbaşkanının iradesini etkilemeye yönelik olmak kaydıyla üçüncü kişilere uygulanan cebirle de işlenebilir. Başka bir deyişle cebre maruz kalan kişi ile cebir dolayısıyla iradesi etkilenen kişi birbirinden farklı olabilir ${ }^{101}$. Asıl olan cebrin, mağduru kendisinden istenen şeyi gerçekleştirmeye zorlaması ve iradesini etkileme hususunda elverişli olmasıdır ${ }^{102}$. Kanaatimizce hükûmet başkanının istifa etmesi amacıyla ülke genelinde şahıslara karşı kullanılan cebir, ülke güvenliğine ilişkin politikalardan da sorumlu olan hükûmet başkanının iradesini etkilemeye elverişli olabilecektir. Nitekim ülkemizde faillerin, hükûmeti istifaya zorlamak amacıyla kendilerine tevdi edilen teçhizatı hukuka aykırı olarak kullanmaları, bunu TSK'ya ait olan zırhlı araçları sokaklarda yürütmek suretiyle gerçekleştirmeleri, hükûmete karşı suçun ilk icra hareketi sayılmıştır ${ }^{103}$. Aynı amaçla işlenen ve hükûmet başkanının iradesini etkilemeye elverişli olan kamusal binaların tahribi ya da bombalanması gibi eylemler de hükûmete karşı suça sebebiyet verirler.

Cebrin özellikle üçüncü kişileri hedef aldığı durumlar, suçun TÖDAS’ın 1. maddesinde yer alan "Şahısların hayatı için tehlike teşkil ettiği ölçüde bomba, el bombası, roket, otomatik ateşli silah veya bombalı mektup veya koli kullanmak suretiyle işlenen suçlar" başta olmak üzere geri vermeyi gerektiren fiillerle işlenebileceğini ortaya koymaktadır.

TÖDAS, taraf devletlerin belirli fiilleri siyasi suç sayma yönündeki takdir yetkilerini sınırlayan bir sözleşmedir. Bu husus TÖDAS’’ açıklayan raporda belirtilmiştir. Sözleşmenin bu özelliği sebebiyle devletler TÖDAS’n 1. 2. maddelerinde sayılan fiilleri, siyasi suç sayarak iadeden kaçınamazlar ${ }^{104}$.

99 Yavuz Atar. Türk Anayasa Hukuku. Cumhurbaşkanlığı Sistemi ve Diğer Değişikliklere Göre Güncellenmiş 13. Baskı. Ankara: Seçkin Yayıncilık, 2019, s. 181.

100 Bkz.: Bayraktar, s. 143. Fiilin makamı korumasının sonucu olarak mülga İtalyan CK’nun 118. maddesinde yer alan kral veya naibinin vazifelerini yerine getirmelerini engellemek amacıyla işlenen suçların kralın yardımcılarını da koruduğu ifade edilmekteydi. Bkz.: Luigi Majno, Ceza Kanunu Şerhi Türk ve İtalyan Ceza Kanunları, 2. Cilt, İstanbul: İstanbul Milliyet Matbaasi, 1927, s. 46.

101 Kanunun 108. maddesi bakımından paralel değerlendirme için bkz.: Schmidt, s. 51. Aktaran Üzülmez, s. 682.

102 Bkz.: Üzülmez, s. 178.

103 Bu olayda Mahkeme sanıkların TSK’nın kendilerine tevdi edilen gücünü ve imkanlarını kullanmaları üzerine bu yolla emniyet kuvvetlerini de etkisiz hale getirdikleri olasılıkta amaçlarına ulaşmada hiçbir maddi engelle karşılaşmayacaklarını değerlendirmiştir. Bkz.: Ankara 5. Ağır C.M. Dosya No.: 2014/144, Karar No.: 2018/248, Cumhuriyet Savcilığı Esas No.: 2013/35. T.: 13.4.2018.

104 Bkz.: Bayraktar, s. 176-177. 
Bu husustaki istisna, SİDAS m. 3/2 ve TÖDAS m. 5’te yer almaktadır. Bu iki düzenleme uyarınca devlet kendisine yapılan talep üzerine suçun adi suç niteliği taşıdığını tespit ettiği halde talebin siyasi nedenle yapıldı̆̆ı veya kişinin talep eden devletteki rejime karşı olması sebebiyle iade edildiği takdirde durumunun ağırlaşacağı sonucuna ulaşırsa talebi reddedebilir ${ }^{105}$.

Bu düzenlemeler karşısında terör metotlarıyla işlendiği durumlarda, hükûmete karşı suçun siyasi saik taşıdığı ileri sürülerek, iadeden kaçınılmasının uluslararası normlarla bağdaşmayacağı kanaatindeyiz. Taraf devletin istisnaları gerekçe göstererek talebi reddettiği durumlarda ise fiili yargilamak konusunda sorumluluğu mevcuttur (TÖDAS m. 6 ve 7).

Ülkemize yapılan iade talepleri bakımından, bu hükümler haricinde 6706 sayılı Cezai Konularda Uluslararası Adli İş Birliği Kanunu’nda yer alan düzenlemeler de uygulama alanı bulmaktadır. 6706 sayılı Kanun'da iadesi talep edilen kişinin siyasi görüşleri nedeniyle bir soruşturma veya kovuşturmaya maruz bırakılacağına veya cezalandırılacağına ya da işkence veya kötü muameleye maruz kalacağına dair kuvvetli şüphe sebeplerinin bulunması (m. 11/1-b) ve iade talebine esas teşkil eden fiilin düşünce suçu, siyasi suç veya siyasi suçla bağlantılı bir suç olması (m. 11/1-c-1) Türkiyeden yabancı devlete, iadenin kabul edilmeyeceği haller arasında düzenlenmiştir. Bununla beraber Kanunun 11/1-c-1 maddesi çerçevesinde, iade talebine esas teşkil eden fiilin düşünce suçu, siyasi suç veya siyasi suçla bağlantılı bir suç olması halinde iade talebinin dayanağını teşkil eden fiilin bütün unsurları, özellikle işleniş şekli, suçun işlenişinde kullanılan araçların veya ortaya çıkan sonuçların ağırlığı dikkate alınarak fiil siyasi suç olarak kabul edilmeyebilir. Soykırım ve insanlığa karşı suçlar, siyasi suç olarak kabul edilmez (m. 11/2). Uluslararası normlarla paralel nitelik taşıyan bu düzenlemeler dolayısıyla başka ülkelerde siyasi iktidara karşı kullanılabilecek cebir mahiyeti taşıyan fiiller bakımından ülkemize yapılan iade taleplerinde, suçun siyasi suç olması gerekçesiyle talebin reddedilmesi mümkün değildir.

\section{Sonuç}

Hükûmete karşı suç, siyasi iktidarı hedef alan bir suç tipidir. Failler ya hükûmeti ortadan kaldırmayı ya da görev yapmasını engellemeyi hedeflemektedirler. Cebir kullanarak işledikleri bu suçta faillerin amacı, siyasi faaliyetlerin kendi inisiyatifleri doğrultusunda cereyan etmesini sağlamaktır. Suç tipiyle demokrasi ve milli irade korunmaktadır. Suçla korunan hukuki değer ve failin saiki gözetilerek suç tipinin siyasi suç niteliği taşıdığı anlaşılmaktadır. Bununla beraber hükûmete karşı suçun, suç teşkil eden adi nitelikteki bir fiilin siyasi saikle işlenmesi suretiyle vücut bulabilmesi, tam ve nisbi siyasi suç ayrımı çerçevesinde hükûmete karşı suçu nisbi siyasi suç olarak değerlendirmemize yol açmaktadır. Cebrin suçun unsurunu teşkil etmesi karşısında ise hükûmete karşı suç nisbi siyasi suçlar arasında muhtelit siyasi suç olarak değerlendirilmelidir.

Geri verme kurumu bakımından aslolan siyasi suçlarda iadenin uygulanmamasıdır. Hükûmete karşı suç, bu hususta istisnaların uygulama alanı bulduğu bir suç tipidir. Öncelikle 2017 tarihli Anayasa 
değişikliği referandumu sonrasında hükûmet başkanlığı ile devlet başkanlığının birleşmiş olması, suçun cumhurbaşkanına uygulanacak olan cebirle işlenebileceğini ortaya koymakta ve SİDAS’n 3/3. maddesinde de düzenlenmiş olan Belçika kuralının uygulanabileceği bir duruma tekabül etmektedir. Belçika kuralının kişiye değil makama getirilmiş bir istisna olması dolayısıyla makamda vekaleten bulunan kişiler de bu istisnadan yararlanabilirler ${ }^{106}$. Anayasanın 106. maddesinin 2. fikrasında cumhurbaşkanı yardımcısının, cumhurbaşkanına vekalet edeceği durumlar düzenlenmiştir. $\mathrm{Bu}$ durumlar söz konusu olduğu takdirde suçun konusu olan cumhurbaşkanı yardımcısına karşı işlenebilecek fiiller de Belçika kuralı çerçevesinde ele alınmalıdır.

Cebir, mağduru kendisinden istenen şeyi gerçekleştirmeye zorlaması ve iradesini etkileme hususunda elverişli olması halinde üçüncü kişilere karşı da uygulanabilirr ${ }^{107}$. Kanaatimizce hükûmet başkanının istifa etmesi amacıyla ülke genelinde şahıslara karşı kullanılan cebir, ülke güvenliğine ilişkin politikalardan da sorumlu olan hükûmet başkanının iradesini etkilemeye elverişli olabilecektir. Belirli uluslararası Sözleşmelerde tanımlanan fiiller ve özellikle şahısların hayatı için tehdit teşkil eden silahlarla gerçekleştirilen eylemler bakımından suçun siyasi suç olduğu gerekçesiyle geri vermeden kaçınılamaz. Bu husustaki düzenlemelerin yer aldığı TÖDAS, 1. maddesinde terör eylemlerinin siyasi suç, siyasi suça murtabit suç veya siyasi nedenle işlenmiş suç sayılamayacağını düzenlemiştir. Sözleşme 1. maddesinde terör eylemlerini kategorize etmiş, 2. maddesinde bu kategorilere girmese de şahısların hayat, vücut bütünlüğü veya hürriyeti aleyhine işlenen bir şiddet eylemi ya da vahim bir suçu siyasi suç, siyasi suça murtabit suç veya siyasi nedenle işlenmiş suç saymama konusunda takdir yetkisi tanınmıştır (m. 2). Ayrıca iade talebini kabul etmeyen devlete Sözleşmenin 1. maddesinde sayılan suçları işlediğinden şüphe edilen kişiyi yargılama yükümlülüğü getirilmiştir (m. 6 ve 7).

\section{Kaynaklar}

Artuk, Mehmet Emin, Ahmet Gökcen, Mehmet Emin Alşahin ve Kerim Çakır. Ceza Hukuku Genel Hükümler. Yenilenmiş Gözden Geçirilmiş 14. Baskı, Ankara: Adalet Yay., 2020.

Atar, Yavuz. Türk Anayasa Hukuku. Cumhurbaşkanlığı Sistemi ve Diğer Değişikliklere Göre Güncellenmiş 13. Baskı. Ankara: Seçkin Yayıncılık, 2019.

Aygün Eşitli, Ezgi. "Anayasayı İhlal Suçu”. Ankara Üniversitesi Hukuk Fakültesi Dergisi. C.: 65, S.: 4, 2016, ss. 1689-1724.

Bayraktar, Köksal. Siyasal Suç. İstanbul: Fakülteler Matbaası, 1982.

Donay, Süheyl. “Tedhişçiliğin Cezalandırılması Hakkında Avrupa Sözleşmesi”. İÜHFM. 43/1-4, Temmuz 2011, ss. $417-430$.

Erem, Faruk, "Ceza Hukukunda "Cebir" Kavramı", Yargıtay Dergisi, C.: 16, S. 1-2, Ocak-Nisan 1990, ss. 94-97. Ersoy, Yüksel. Çalışma Hürriyetine Karşı Suçlar (TCK m. 201 ve 275 sayılı kanunun ilgili hükümleri). Ankara: Ankara Üniversitesi Basımevi, 1973.

Gökcen, Ahmet. Halkı Kin ve Düşmanlığa Açıç̧a Tahrik Cürmü (TCK m. 312/2), Ankara: Liberal Düşünce Topluluğu Yay., 2001.

Gözler, Kemal. Türk Anayasa Hukuku. 3. Baskı. Bursa: Ekin Yayınları, 2019.

106 Bkz.: Bayraktar, s. 143.

107 Bkz.: Üzülmez, s. 178. 
Hafızoğulları, Zeki, Özgür Küçüktaşdemir. “Cumhurbaşkanına Suikast ve Fiili Saldırı Suçu”. Prof. Dr. Nevzat Toroslu’ya Armağan. Ankara Üniversitesi Yay. No.: 459, 2015, ss. 569-574.

Hafızoğulları, Zeki, Muharrem Özen. Türk Ceza Hukuku Özel Hükümler Millete ve Devlete Karşı Suçlar. Ankara: US-A Yay., 2016.

Hassan, Ümit. “Siyasi Suç Kavramı”. Ankara Üniversitesi SBF Dergisi. Y.: 1971, C.: 26, S.: 1, ss. 197 - 217.

İçel, Kayıhan. Ceza Hukuku Genel Hüikümler. Yenilenmiş 5. Bası, İstanbul: Beta Yay., 2018.

İçel, Kayıhan, Süheyl Donay. Karşılaştırmalı ve Uygulamalı Ceza Hukuku. İstanbul:Beta, 1987.

Koca, Mahmut, İlhan Üzülmez. Türk Ceza Hukuku Genel Hükümler. Gözden Geçirilmiş ve Güncellenmiş 13.

Baskı. Ankara: Seçkin Yayıncılık, 2020.

Küçüktaşdemir, Özgür. Türk Ceza Hukukunda Cebir ve Manevi Cebir. Ankara: Seçkin Yayıncılık, 2012.

Mahmutoğlu, Fatih Selami, Serra Karadeniz. Türk Ceza Kanunu Genel Hükümler Şerhi. İstanbul: Beta Yay., 2017.

Majno, Luigi. Ceza Kanunu Şerhi Türk ve İtalyan Ceza Kanunları. 2. Cilt. İstanbul: İstanbul Milliyet Matbaası, 1927.

Özbudun, Ergun. Türk Anayasa Hukuku. Ankara: Yetkin, 2019.

Özek, Çetin. Siyasi İktidar Düzeni ve Fonksiyonları Aleyhine Cürümler (TCK m. 146-151, 168-173). 1. Baskı. İstanbul: Cezaevi Matbaası, 1967.

Özgen, Eralp. Suçluların Geri Verilmesi, Ankara: Ankara Üniversitesi Hukuk Fakültesi Yay., 1961.

Özgenç, İzzet. Suç Örgütleri. Gözden Geçirilmiş ve Genişletilmiş 13. Bası. Ankara: Seçkin Yayıncılık, 2020.

Parlar, Ali. Türk Ceza Kanunu Şerhi Cilt: 2. Ankara: Bilge Yay., 2015.

Salihoğlu, Hadi, Ali Parlar, Mustafa Öztürk. Uygulamada Terör Suçları Devlete ve Anayasal Düzene Karşı Suçlar. Ankara: Bilge Yay., 2018.

Sınar, Hasan. "Siyasi Suç Üzerine Bir İnceleme”. İÜHFM, C.: LVIII, S.: 1-2, 2000, ss. 53-77.

Soyaslan, Doğan. Ceza Hukuku Özel Hükümler. Güncelleştirilmiş 12. Baskı, Ankara: Yetkin Yayınları, 2018.

Şensoy, Naci. "Siyasi Suçlar”. İÜHFM, 1951, C.: XVII, S.: 1-2, ss. 53-74.

Üzülmez, İlhan. Yeni Türk Ceza Kanunu’nun Hürriyete Karşı İşlenen Suçlar Sistemi Çerçevesinde Tehdit, Şantaj ve Cebir Suçları, Ankara: Turhan Kitabevi, 2007.

Yaşar, Osman, Hasan Tahsin Gökcan ve Mustafa Artuç. Yorumlu-Uygulamalı Türk Ceza Kanunu, Cilt VI, m. 257-345. Ankara: Adalet Yay., 2010.

Yüce, Turhan Tûfan. Ceza Hukuku Dersleri Cilt:1. Manisa: Şafak Basım ve Yay., 1982.

\section{Online Kaynaklar}

"Roma Statue of the International Criminal Court". E.T.: 30.05.2021. https://www.icc-cpi.int/resource-library/ documents/rs-eng.pdf

"Statue of the International Tribunal For Rwanda". E.T.: 30.05.2021. https://legal.un.org/avl/pdf/ha/ictr_EF.pdf

"Updated Statute of the International Criminal Tribunal for the Former Yugoslavia. E.T.: 30.05.2021. https:// www.icty.org/x/file/Legal\%20Library/Statute/statute_sept09_en.pdf 